\title{
Chemical Analysis of Hydrolysates and Cell Extracts of Nocardia pellegrino
}

\author{
HALINA MORDARSKA, MARIAN MORDARSKI, and DALILA PIETKIEWICZ
}

\begin{abstract}
Department of Biosynthesis, Institute of Immunology and Experimental Therapy, Polish Academy of Sciences, Wroclaw, and Department of Microbiology, Pomeranian Medical School, Szczecin, Poland
\end{abstract}

Hydrolysates and cell extracts of 23 strains of Nocardia pellegrino were analyzed chemically. The components of the cell extracts indicated that the strains cannot be regarded as members of the genus Mycobacterium but that they belong to the genus Nocardia. Moreover, it is concluded that the strains of $N$. pellegrino constitute a uniform taxon and produce an LCN-A (lipid characteristic for Nocardia) similar to that produced by $N$. calcarea.

In a previous paper (13), 23 strains of Nocardia pellegrino were characterized by standardized bacteriological tests which revealed a marked similarity of these strains to other nocardiae. The results were entirely consistent with those of Juhasz and Bönicke (7), who questioned the placement of these microorganisms in the genus Mycobacterium and proposed their reclassification in the genus $\mathrm{No}^{-}$ cardia. Strains of $N$. pellegrino, in contrast to those of acid-fast bacilli, are characterized by a triphasic developmental cycle, stain negatively by the Ziehl-Neelsen method, produce reddishbrown pigments, and metabolize metanitrophenol. Moreover, they are insensitive to Mycobacterium phages but are sensitive to Nocardia phages (2). Mycolic acids, sensu stricto, have not been found in the cells of $N$. pellegrino, although nocardomycolic acids have been reported ( 8 ).

This investigation is concerned with a chemical analysis of the hydrolysates and cell extracts of $N$. pellegrino strains for chemotaxonomic purposes.

Bacterial strains. The designations and sources of the 23 strains of $N$. pellegrino studied are given in Table 1.

Media and methods. Cells were incubated for 3 to 5 days at $37 \mathrm{C}$ in submerged culture in modified Sauton's medium (12) and in glucosepeptone broth 79 (14). After checking the purity of the cultures, $1 \%$ formaldehyde was added, and $24 \mathrm{~h}$ later the mycelium was washed and dried. LCN-A (lipid characteristic for Nocardia) was analyzed by thin-layer chromatography of ethanol-ether cell extracts (10). Sugars and amino acids were demonstrated by paper chromatography of acid hydrolysates of undefatted and defatted mycelium $(1,9)$. The standard lipids used as controls were obtained from $N$. asteroides (received from the Mayo Clinic, Rochester, Minn.), N. brasiliensis 154, $S$. griseus 22, $S$. olivaceus 2238 , and $N$. calcarea IMET 7177 (12).

Acid hydrolysates of cells of the 23 strains studied contained the following amino acids: alanine, arginine, cystine, cysteine, phenylalanine, glycine, histidine, aspartic acid, mesodiaminopimelic acid, leucine, lysine, methionine, valine, proline, threonine, and tyrosine.

In Table 1 are listed the sugar components of the hydrolysates of the whole cells.

Alcohol-ether extracts of the strains showed the presence of LCN-A with a lower $R_{f}$ value ("calcarea type") than that of the reference LCN-A from standard strains of $N$. asteroides ("asteroides type") (6, 11) (Fig. 1).

The results of the qualitative analysis of cells propagated on both of the culture media mentioned above were identical with regard to the amino acid and sugar compositions of defatted and undefatted cells. In spite of the lack of quantitative assays, a higher content of lipids, especially LCN-A of the calcarea type, was evident in extracts of cells grown in modified Sauton medium than in those from cells grown in glucose-peptone broth 79 . On the other hand, the contents of sugars and amino acids were higher in the hydrolysates of cells grown in Sauton's medium.

The lack of unified opinions and of methods for differentiating nocardiae and mycobacteria is a serious obstacle to the classification of these microorganisms. This statement particularly applies to species with an indistinct taxonomic profile: such species are probably 
TABLE 1. Sugar composition of whole-cell hydrolysates of $N$. pellegrino strains

\begin{tabular}{|c|c|c|c|c|c|c|}
\hline \multirow[b]{2}{*}{ Strains } & \multirow[b]{2}{*}{ Sources } & \multicolumn{5}{|c|}{ Sugars } \\
\hline & & $\begin{array}{l}\text { Arabinose } \\
\text { and } \\
\text { galactose }\end{array}$ & Glucose & Mannose & Ribose & Rhamnose \\
\hline "Budapest" & $\begin{array}{c}\text { Institute of Tuberculosis, } \\
\text { Budapest }\end{array}$ & + & + & + & Trace & Trace \\
\hline I.G. & $\begin{array}{l}\text { Institute of Tuberculosis, } \\
\text { Warsaw }\end{array}$ & + & + & + & + & Trace \\
\hline Prague II & $\begin{array}{l}\text { Institute of Tuberculosis, } \\
\text { Prague }\end{array}$ & + & + & + & + & Trace \\
\hline Sn 5101 & $\begin{array}{l}\text { Research Institute, } \\
\text { Borstel }\end{array}$ & + & + & + & Trace & Trace \\
\hline Sn 5102 & $\begin{array}{l}\text { Research Institute, } \\
\text { Borstel }\end{array}$ & + & - & - & Trace & - \\
\hline Sn 5103 & $\begin{array}{l}\text { Research Institute, } \\
\text { Borstel }\end{array}$ & + & - & - & Trace & - \\
\hline Sn 5104 & $\begin{array}{l}\text { Research Institute, } \\
\text { Borstel }\end{array}$ & + & - & - & Trace & - \\
\hline Sn 5105 & $\begin{array}{l}\text { Research Institute, } \\
\text { Borstel }\end{array}$ & + & - & - & Trace & - \\
\hline Sn 5106 & $\begin{array}{l}\text { Research Institute, } \\
\text { Borstel }\end{array}$ & + & - & - & Trace & - \\
\hline Sn 5107 & $\begin{array}{l}\text { Research Institute, } \\
\text { Borstel }\end{array}$ & + & + & + & + & Trace \\
\hline Sn 5108 & $\begin{array}{l}\text { Research Institute, } \\
\text { Borstel }\end{array}$ & + & - & - & Trace & - \\
\hline Sn 5109 & $\begin{array}{l}\text { Research Institute, } \\
\text { Borstel }\end{array}$ & + & + & - & Trace & - \\
\hline Sn 5110 & $\begin{array}{l}\text { Research Institute, } \\
\text { Borstel }\end{array}$ & + & + & - & Trace & - \\
\hline Sn 5111 & $\begin{array}{l}\text { Research Institute, } \\
\text { Borstel }\end{array}$ & + & - & - & Trace & - \\
\hline Sn 5112 & $\begin{array}{l}\text { Research Institute, } \\
\text { Borstel }\end{array}$ & + & - & - & Trace & - \\
\hline SO & $\begin{array}{l}\text { Pasteur Institute, } \\
\text { Lille }\end{array}$ & + & + & + & Trace & Trace \\
\hline SR & $\begin{array}{l}\text { Pasteur Institute, } \\
\text { Lille }\end{array}$ & + & + & + & Trace & Trace \\
\hline 81 & $\begin{array}{l}\text { Pasteur Institute, } \\
\text { Lille }\end{array}$ & + & + & + & Trace & Trace \\
\hline 107 & $\begin{array}{l}\text { Pasteur Institute, } \\
\text { Lille }\end{array}$ & + & + & + & Trace & Trace \\
\hline 327 & $\begin{array}{l}\text { Pasteur Institute, } \\
\text { Lille }\end{array}$ & + & + & + & Trace & Trace \\
\hline 330 & $\begin{array}{l}\text { Pasteur Institute, } \\
\text { Lille }\end{array}$ & + & + & + & Trace & Trace \\
\hline 906 & $\begin{array}{l}\text { Pasteur Institute, } \\
\text { Lille }\end{array}$ & + & + & + & Trace & Trace \\
\hline $906 \mathrm{~B}$ & $\begin{array}{l}\text { Pasteur Institute, } \\
\text { Lille }\end{array}$ & + & + & + & Trace & Trace \\
\hline
\end{tabular}

natural links between artificially arranged groups of microorganisms, such as $N$. pellegrino, whose systematic position has only recently been established (3).

Previously $(11,12)$ it was shown that the type of LCN-A analogue produced by nocardiae may be used to divide these orga- nisms into two subgroups: "asteroides" and "calcarea." The LCN-As present in members of these subgroups differ markedly with respect to their $R_{f}$ values. The asteroides subgroup comprises all the nocardiae sensu stricto (type IV cell wall and LCN-A of the "asteroides type") with $N$. asteroides as the representative. 


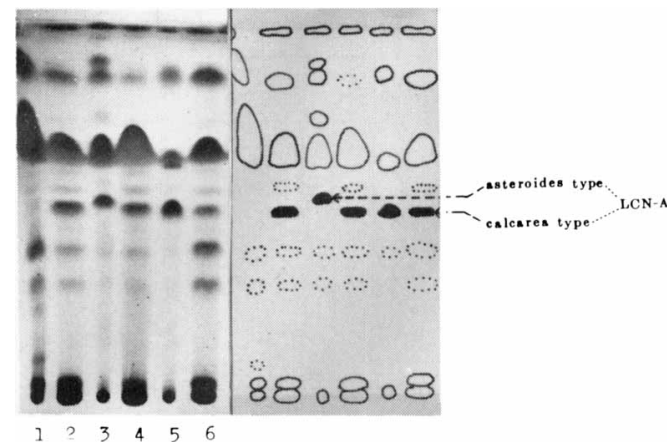

FIG. 1. Triplicate thin-layer chromatography of cell extracts of pellegrino strains. Developing system: petroleum ether (bp 40-60 C)-diethyl ether-glacial acetic acid (85:15:1): 2-Sn 5101, 4-Sn 5102, 6-Sn 5103; standards: $I-S$. griseus 22, 3-N. asteroides U.S.A., 5-N. calcarea IMET 7177.

TABLE 2. Chemotaxonomic characters of $N$. pellegrino and related taxa

\begin{tabular}{|c|c|c|c|c|c|}
\hline \multirow[b]{2}{*}{ Taxa } & \multirow[b]{2}{*}{ Meso-DAP } & \multicolumn{2}{|c|}{ Sugars } & \multicolumn{2}{|c|}{ LCN-A } \\
\hline & & Arabinose & Galactose & $\begin{array}{c}\text { Asteroides } \\
\text { type }\end{array}$ & $\begin{array}{c}\text { Calcarea } \\
\text { type }\end{array}$ \\
\hline N. pellegrino & + & + & + & - & + \\
\hline$N$. asteroides & + & + & + & + & - \\
\hline N. calcarea & + & + & + & - & + \\
\hline Mycobacterium & + & + & + & - & - \\
\hline
\end{tabular}

In the calcarea subgroup are placed all strains with a type IV cell wall but with LCN-A of the calcarea type. The representative of this subgroup is $N$. calcarea. The calcarea type lipid was found in strains of Mycobacterium rhodochrous (11), the correct generic assignment of which is also uncertain $(4,5)$. Preliminary data on the structure of nocardomycolic acids suggest that the acids from $M$. rhodochrous may have a different chemical structure from those of nocardiae sensu stricto (6).

The chemotaxonomic characters of the $N$. pellegrino strains studied are summarized in Table 2. All of the strains show the calcarea type of LCN-A and therefore should be included in the calcarea subgroup. This finding definitely undermines the classification of these strains in the genus Mycobacterium and at the same time confirms their similarity to members of the genus Nocardia.

The number and type of amino acids in the hydrolysates of whole cells of the 23 strains of $N$. pellegrino were identical. Only the sugar composition varied in different strains. Galactose and arabinose were present in all of the strains, but xylose was not detected. This is consistent with sugar type A, which is characteristic for nocardiae, mycobacteria, and most of the corynebacteria. A majority of the strains also contained glucose and mannose and traces of ribose and rhamnose. However, these sugars are not diagnostically significant, occurring also in many other members of the order Actinomycetales (9). The group of strains of French origin had an entirely uniform chemical composition.

The chemotaxonomic characters of the strains studied show that they form a uniform taxon with an LCN-A similar to that of $N$. calcarea and that they are different from mycobacteria.

We thank A. Tacquet for some of the strains used ir this study.

\section{REPRINT REQUESTS}

Address requests for reprints to: Marian Mordarski, Department of Biosynthesis, Institute of Immunology and Experimental Therapy, Polish Academy of Sciences, Wroclaw, ul, Chalubinskiego 4, Poland.

\section{LITERATURE CITED}

1. Becker, B., M. P. Lechevalier, R. E. Gordon, and H. A. Lechevalier. 1964. Rapid differentiation between Nocardia and Streptomyces by paper chromatography of whole-cell hydrolysates. Appl. Microbiol. 12:421-423.

2. Castelnuovo, G., G. Bellezza, M. E. Duncan, and J. Asselineau. 1964. Etude sur les mycobactéries et les nocardiae. I. Constitution antigénique. II. 
Relations sérologiques entre mycobactéries et nocardiae. III. Sensibilité aux phages. Ann. Inst. Pasteur 107:828-844.

3. Cross, T., and M. Goodfellow. 1973. Taxonomy and classification of the actinomycetes p. 11. In G. Sykes and F. A. Skinner (ed.), Actinomycetales: characteristics and practical importance. Academic Press Inc. New York.

4. Goodfellow, M. 1971. Numerical taxonomy of some nocardioform bacteria. J. Gen. Microbiol. 69:33-38.

5. Goodfellow, M., A. Fleming, and M. J. Sackin. 1972. Numerical classification of "Mycobacterium" rhodochrous and Runyon's group IV my cobacteria. Int. J. Syst. Bacteriol. 22:81-98.

6. Goodfellow, M., D. E. Minnikin, P. V. Patel, and H. Mordarska. 1973. Free nocardomycolic acids in the classification of nocardias and strains of the "rhodochrous" complex. J. Gen. Microbiol. 74:185-188.

7. Juhasz, S. E., and R. Bönicke. 1965. Mycobacterium oder Nocardia pellegrino? Beitr. Klin. Tuberc. 130:155-169.

8. Lanéelle, M. A., J. Asselineau, and G. Castelnuovo. 1965. Etudes sur les mycobactéries et les nocardiae. IV. Composition des lipides de $\mathbf{M y c o}$ bacterium rhodochrous, $M$. pellegrino, et de quelques souches de nocardiae. Ann. Inst. Pasteur 108:62-82.

9. Lechevalier, M. P. 1968. Identification of aerobic actinomycetes of clinical importance. J. Lab. Clin. Med. 71:934-944.

10. Mordarska, H. 1968. A trial of using lipids for the classification of actinomycetes. Arch. Immunol. Ther. Exp. 16:45-50.

11. Mordarska, H., M. Mordarski, and M. Goodfellow. 1972. Chemotaxonomic characters and classification of some nocardioform bacteria. J. Gen. Microbiol. 71:77-86.

12. Mordarska, H., and M. Mordarski. 1970. Cell lipids of Nocardia p. 47. In H. Prauser (ed.), The Actinomycetales. Gustav Fischer Verlag. Jena.

13. Pietkiewicz, D., J. Andrzejewski, and H. Mordarska. 1973. Nocardia pellegrino: I. Versuch einer morphologischen und biochemischen Charakteristik der Art. Z. Bakteriol. 13:171-172.

14. Prauser, H., and R. Falta. 1968. Phagensensibilität, Zwellwand-Zusammensetzung und Taxonomie von Actinomyceten. Z. Allg. Mikrobiol. 8:39-46. 